\title{
Preface to the 2007 Edition
}

\section{THE DOMESTIC GOES GLOBAL}

Can we conceive of globalization without migrant domestic workers? In the preface to the first edition of this book, I argued that the work of Mexican and Central American domestic workers was critical to keeping afloat the culture and the economy of Los Angeles, and more generally, the United States. I still think this is true. But as I look back now, I am struck by the pervasiveness of this pattern around the globe. Women from countries as varied as Peru, the Philippines, Moldavia, Eritrea, and Indonesia are leaving their families, communities, and countries to migrate thousands of miles away to work in the new worldwide growth industry: paid domestic work.

Paid domestic workers in the United States have historically been disregarded and treated as though they were invisible in the homes where they work. So it is too with migrant domestic workers on the global scene. Both the celebrants and critics of globalization have rarely paused to consider the importance of migrant paid domestic workers. Not only were the modernization theorists wrong in prematurely predicting the demise of paid domestic work in modern societies, but neither they nor the globalization theorists who followed them predicted or acknowledged the role of migrant domestic workers in the era of globalization and postindustrial societies. I think the reason they have not paid attention is relatively simple: the cleaning and caring that takes place in private homes is seen as women's work. For many observers, shipping containers, overseas factories, and international banking are the stuff of globalization. But a group of policy makers and academics, most of them working from a feminist perspective, has been paying ample attention to the recent expansion and dispersal of transnational migrant domestic workers. A plethora of recent research-a selected list of which appears at the end of this preface-illuminates the presence of foreign domestic 
workers in Europe, the Gulf States of the Middle East, Israel, Hong Kong, Singapore, Taiwan, Malaysia, and in Canada and the United States. Meanwhile, particular nations around the globe have emerged as the places producing migrant domestic workers. The domestics' countries of origin are diverse, as are the circumstances situating their migration and domestic employment, but they share a status as the new cleaners and caregivers of the twenty-first century.

We live in the age of migration. Around the world, at least 185 million people, and perhaps as many as 200 million, reside in countries other than those where they were born. Why are so many people leaving their countries of origin? The legacies of colonialism, neocolonialism, imperialism, civil wars, imperial wars, uneven development, and the contemporary shock effects of neoliberalism and political shifts have laid the structure for today's global migration. Meanwhile, innovations in technology, particularly in transportation and communications, have facilitated this vast human movement. International migration occurs through legal, quasi-legal, and illegal channels. It is important to recognize, however, that in many cases, deliberate labor-recruitment programs have helped to activate and maintain international labor migration. These are generally inaugurated for employer interests in the receiving society, and they are facilitated by receiving-state government, and sometimes bilateral, agreements. Such programs rely on the state to condone a particular type of legal migration predicated on the denial of migrants' basic human, labor, and civil rights.

Not long ago, migrants were mainly men. In fact, the international labor migration of men was a key feature of industrialization. During peak periods of modernization and industrialization, the industrial state relied on the recruitment and importation of men-usually men from poorer, often colonial societies--to do "men's work." Chinese, Filipino, Japanese, Irish, Italian, and Mexican men, for instance, all took turns as recruits who were brought in to build the infrastructure of an industrializing America. These migrants built canals and railroads, dug deep in mines, stoked factory furnaces, laid irrigation pipes, and provided the labor for large-scale agribusiness. In some instances, family members were allowed to join them, but in many cases, especially those involving immigrant groups perceived as non-white, dependent family members were denied admission to the migrant-receiving societies. Women and children were perceived 
as burdens who would consume resources, and they were also seen to be demographically and racially undesirable as permanent members of the society. For these reasons, the reproduction of families and communities was forbidden. In many instances, government legislation enforced these prohibitions on the permanent incorporation of workers and their families. It was labor, not human beings, that was being recruited. The Bracero Program, which issued nearly five million temporary labor contracts to Mexican agricultural laborers in the United States between 1942 and 1964, and the Guest Worker Program, which relied on Turkish and Algerian men to rebuild cities and toil in the factories of Europe after World War II, are the exemplars of these modern systems, in which labor recruitment relied not only on men, but on subordinated men who were subjected to meticulous rules and regulations and to rigorous, dehumanizing bodily inspections.

Today, industry and manufacturing are no longer the primary fulcrums driving labor migration. To be sure, there is still plenty of movement, but it is varied. In a globalized world, factories migrate to places overseas that offer cheaper labor. High-tech and highly educated professionals have now joined the international migration, as have the legions of migrant domestic workers who crisscross the globe, from south to north, from east to west. Consequently, in some sites, we are seeing an oversupply of male migrant labor and the saturation of labor markets for working men. In parts of Europe, Latin American migrant women-mostly Ecuadorian and Peruvian women working as domestics-far outnumber their male peers. In places as diverse as Italy, the Middle East, Taiwan, and Canada, Filipina migrant women working as caregivers and cleaners far outnumber Filipino migrant men. And as I noted in the first edition of this book, in Los Angeles newly arrived Latina immigrant women find jobs much more easily than their husbands and brothers, because of the steady demand for live-in domestic workers.

The seemingly unquenchable demand for domestic workers has expanded in affluent societies around the globe. But the demand is activated in different ways by different nations. Just as the United States and the Western European nations relied on state-operated systems of labor recruitment for male laborers in the mid-twentieth century, systems premised on the denial of political and civil rights, so too have a series of nations now activated programs devised to 
recruit and maintain a subordinated class of migrant domestic workers in their societies. Many of the newly industrialized Asian nations, such as Taiwan, Hong Kong, and Singapore, as well as Middle Eastern oil-rich nations, such as Saudi Arabia, Kuwait, and the United Arab Emirates, rely on state-legislated projects to recruit migrant domestic workers. The migrant domestic workers employed in these societies hail from poorer nations that are desperate to capture migrant remittances for foreign exchange, and to diffuse the social and political pressures created by unemployment. Consequently, nations such as the Philippines, Indonesia, Sri Lanka, and Thailand actively promote the out-migration of women into global domestic worker labor markets.

The nation-states from which domestic workers migrate have responded to these pressures in varied ways. The Philippines not only facilitates the out-migration of Filipina women as domestic workers, but it honors the return migrant domésticas as "heroes," to emphasize their contributions to building and sustaining the Philippine nation. The Philippines does make some effort to intervene on behalf of the domestic workers, but when Filipino diplomats and labor attachés attempt to impose fair labor standards in the countries where Filipinas go, they often discover that their bargaining power is weak, especially in contexts where migrant women are arriving from other, competing countries. Meanwhile, nations such as Bangladesh act in a more paternalistic, patriarchal way, attempting to thwart abuses by prohibiting the out-migration of women as foreign domestic workers. By contrast, Mexico-the nation that sends by far the most immigrants to the United States, a fair number of whom wind up working as domésticas-remains curiously silent on the incorporation of Mexican women as workers in private American homes.

When nation-states collaborate on contract-labor programs for domestic workers, the regulations are usually geared toward the control and submission of these workers, and not toward ensuring their rights. Women who find themselves in these jobs face not only racist and sexist discrimination, and second-class status as migrant foreigners, but they are also subjected to inhumane policies that hark back to another century. Migrant domestic workers may be required to remain with one employer for the duration of their contract period, regardless of the treatment they might receive. If they are unhappy with their job, they may not seek out another one, remaining stuck in 
a feudal-like situation. Some must sign oaths promising loyalty and docility. Other rules specify how they may dress and wear their hair, and prohibit makeup or lipstick. The confiscation of passports by employers is common. Domestic workers may also be subjected to medical surveillance designed to ensure they are not pregnant, and may be prohibited from leaving the homes where they work except for perhaps a few hours on one afternoon a week. Some are subjected to beatings or sexual abuse, but have no escape or access to legal recourse. The anthropologist Nicole Constable chronicled and analyzed the multiple ways in which Filipina domestic workers in Hong Kong are controlled and disciplined by their Chinese employers, the state, and employment agencies. These types of policies and practices, in different forms, appear around the globe, wherever the state actively intervenes in the recruitment and retention of a migrant domestic worker labor force. Just as slavery produced runaway slaves, many times these conditions result in "runaway maids." In the worst-case scenarios, these sorts of institutional conditions have resulted in the tragic deaths of migrant domestic workers, as we have seen in Singapore and Kuwait. Human rights advocates around the globe have raised their voices against such abuses, but the institutionalized violation of domestic workers' human rights has not received as much public attention and action as has been directed toward thwarting the illegal trafficking of women and girls.

In countries such as the United States, where neither the sending nor the receiving state programmatically intervenes in the recruitment and maintenance of migrant domestic workers, the situation is different. To be sure, abuses abound and paid domestic workers still suffer the indignities described in this book; but laws and regulations do not tie migrant domestic workers to their jobs, as they do in societies like Kuwait or Taiwan. Moreover, there are labor-protection laws on the books, and legal and community advocates working for enforcement of those rules. We know that, for domestic workers and agricultural workers, who were historically excluded from these pacts, the reach of these laws has been limited. Labor activists, legislators, and domestic workers themselves, however, continue to push for change, as they did in 2006, when they tried to change California legislation to allow overtime labor protections for live-in domestic workers and for personal attendants. Latina immigrant domestic workers in the United States hold a range of legal statuses, from 
those who are undocumented to those who are naturalized U.S. citizens. To be sure, these women were marching in the streets during the Spring 2006 national mobilizations for immigrant legal rights. Unlike their global peers working on temporary contract programs, many immigrant domestic workers in the United States already live with their own families in immigrant communities in American cities, but a massive legalization program would allow them to further improve their labor prospects and better support their families.

Some Latina immigrant workers, in Los Angeles and elsewhere in the United States, do face almost unimaginable forms of abuse and exploitation, but many of them can and do express their dissatisfaction by exiting their bad jobs and finding others. To be sure, financial considerations, legal status, local labor markets, and social networks can either enable or deter new job searches. In the United States today, the most brutal forms of exploitation in domestic work that we see are to be found between co-ethnic, co-national immigrants and employers. These are instances in which immigrant domestic workers are brought here and enslaved by employers from their own countries. The victims of this type of abuse often include child maids, girls as young as ten or twelve, who are kept in extreme isolation and servitude, and subjected to routine beatings and threats. Interestingly, as various media stories have shown, many of the offending employers have been associated with some of the premier international institutions of globalization, such as the World Bank and the United Nations. In such cases, as employees of foreign nationals or of American citizens with permanent residency abroad, the domestic workers may enter with special visas. Once again, the power of the state exerts itself against migrant domestic workers.

While the social trends that create the international flow of migrant domestic workers are diverse, the result is the same: families in the wealthy nations get women from poor nations to do the dirty domestic work, while families from the poor nations lose their mothers and wives. Is this simply a continuation of imperialism? As Barbara Ehrenreich and Arlie Hochschild (2002:11) have astutely noted, rich nations increasingly assume "a role like that of the old-fashioned male in the family-pampered, entitled, unable to cook, clean or find his socks." The poor nations, like the traditional woman, remain mired in domestic work and subservience. As for the migrant female domestic workers, who is left at home to do the care for them? This 
is a big moral question, one with social, political, and economic consequences, to which researchers and policy makers are now devoting more attention.

Meanwhile, it is important to listen to the voices and experiences of the domestic workers themselves. Not all immigrant domestic workers are exploited. In fact, many of them remind us that they are valuable contributors to two societies, the one they left behind and the one in which they work. They value their jobs, and when employers and society offer them social recognition and fair labor conditions, they take satisfaction from their work and their earnings. This, after all, is what these women are looking for as they navigate the globe: dignity, respect, and the opportunity to improve their own lives and those of their family members.

South Pasadena

August 2006 


\section{SOME SOURCES ON MIGRANT DOMESTIC WORKERS AROUND THE GLOBE}

Andall, Jacqueline. 2000. Gender, Migration, and Domestic Service: The Politics of Black Women in Italy. Aldershot, U.K.: Ashgate.

Anderson, Bridget. 2000. Doing the Dirty Work? The Global Politics of Domestic Labour. London: Zed Books.

Constable, Nicole. 1997. Maid to Order in Hong Kong: Stories of Filipina Workers. Ithaca and London: Cornell University Press.

Ehrenreich, Barbara, and Arlie Russell Hochschild, eds. 2002. Global Woman: Nannies, Maids, and Sex Workers in the New Economy. New York: Metropolitan Books.

Gamburd, Michele. 2000. The Kitchen Spoon's Handle: Transnationalism and Sri Lanka's Migrant Housenaids. Ithaca, NY: Cornell University Press.

Lan, Pei-Chia. 2006. Global Cinderellas: Migrant Domestic Workers and Newly Rich Employers in Taiwan. Durham and London: Duke University Press.

Ozeyegin, Gul. 2001. Untidy Gender: Donestic Service in Turkey. Philadelphia: Temple University Press.

Parrenas, Rhacel Salazar. 2001. Serzants of Globalization: Women, Migration, and Domestic Work. Stanford, California: Stanford University Press.

Parrenas, Rhacel Salazar. 2005. Children of Global Migration: Transnational Families and Gendered Woes. Stanford, California: Stanford University Press.

Poniatowski, Birgit, and Carolina Jimenez. 2005. Report on workshop on "Gender and Migration: Domestic Workers from Asia and Latin America," United Nations University, October 19-20.

Oishi, Nana. 2005. Women in Motion: Globalization, State Policies, and Labor Migration in Asia. Stanford, California: Stanford University Press.

Zimmerman, Mary K., Jacquelyn S. Litt, and Christine E. Bose, eds. 2006. Global Dimensions of Gender and Carework. Stanford: Stanford University Press. 